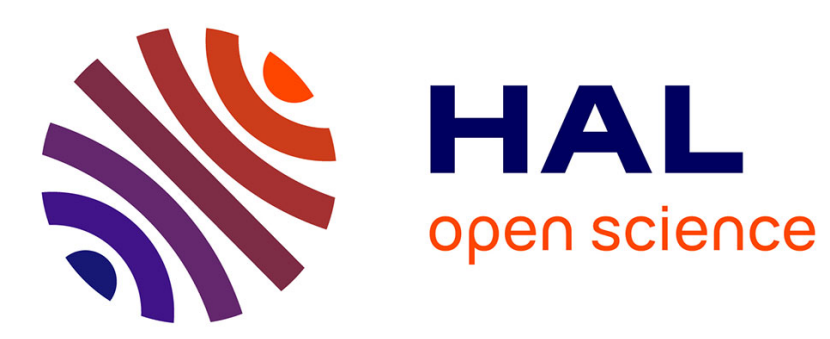

\title{
Estimating uncertainties for urban floods modelling
}

\author{
André Paquier, Pierre Henri Bazin
}

\section{To cite this version:}

André Paquier, Pierre Henri Bazin. Estimating uncertainties for urban floods modelling. La Houille

Blanche - Revue internationale de l'eau, 2014, 6, pp.13-18. 10.1051/lhb/2014057 . hal-01192603

\section{HAL Id: hal-01192603 \\ https://hal.science/hal-01192603}

Submitted on 3 Sep 2015

HAL is a multi-disciplinary open access archive for the deposit and dissemination of scientific research documents, whether they are published or not. The documents may come from teaching and research institutions in France or abroad, or from public or private research centers.
L'archive ouverte pluridisciplinaire HAL, est destinée au dépôt et à la diffusion de documents scientifiques de niveau recherche, publiés ou non, émanant des établissements d'enseignement et de recherche français ou étrangers, des laboratoires publics ou privés. 


\title{
Estimating uncertainties for urban floods modelling
}

\author{
André PAQUIER ${ }^{1}$, Pierre-Henri BAZIN² \\ 1. Irstea, UR HHLY, Unité de Recherche Hydrologie Hydraulique, 5, rue de la Doua - CS70077 - 69626 Villeurbanne - France, \\ andre.paquier@irstea.fr \\ 2.Irstea,URHHLY, pierre-henri.bazin@irstea.fr
}

\begin{abstract}
Because stakes are concentrated in urban environment, flood modelling should be carried out there with high accuracy. However, uncertainties remain important because of:

- the estimate of the inputs, these inputs being either rainfalls, or flows coming from the upstream basin or from the exchanges with the sewage network;

- the complexity of the processes, which includes a frequent change of the flow regime -from subcritical to supercritical and oppositely -, the difficulty in predicting the flow distribution at the street junctions, the oscillations created by waves reflecting against, for instance, obstacles or walls of houses;

- the parameters of the flooded area: variable roughness, very irregular topography, moving obstacles in the streets, water entering the built-up areas, etc.

An assessment of these uncertainties is presented for a few examples coming from laboratory experiments or from the two-dimensional modelling of flood events in French towns. These latter results can be used in order to estimate the range of uncertainty during field studies.
\end{abstract}

Key-words: Urban flood, Hydrodynamic model, 2-D modelling, Uncertainties, Flow regime

\section{Incertitudes lors de la modélisation des inondations en milieu urbain}

RÉSUMÉ. - Compte tenu de la concentration des enjeux en milieu urbain, la modélisation des inondations doit y être effectuée avec le maximum de précision. Or, les incertitudes y sont fortes et tiennent à trois types de facteurs :

- à la définition des apports, que ceux-ci soient les précipitations, les débits venant du bassin amont ou les échanges avec le réseau d'assainissement ;

- à la complexité des processus qui se traduit par le changement fréquent de régime (de torrentiel à fluvial et inversement), par la difficulté de prévoir la répartition des débits aux intersections de rue ou par la création d'oscillations lors des réflexions contre, par exemple, des obstacles ou les façades des bâtiments;

- à la caractérisation du milieu qui s'effectue par : une rugosité variable, une topographie très irrégulière, la présence d'obstacles mobiles, la pénétration de l'eau dans les espaces bâtis, etc.

Pour chacun de ces types de facteurs, une estimation de l'incertitude est présentée à partir d'un ou plusieurs exemples. Ces exemples proviennent généralement d'expérimentations en laboratoire ou de résultats de modèles bidimensionnels d'événements d'inondation dans des villes françaises.

Les valeurs d'incertitude proposées varient fortement en fonction des facteurs mais aussi des variables cibles (hauteurs d'eau ou vitesses) et des caractéristiques du modèle hydrodynamique utilisé. De manière opérationnelle, il est ainsi rare d'obtenir une incertitude inférieure à $10 \%$. Cette incertitude crô̂t souvent si on s'intéresse à des paramètres de plus en plus locaux.

Mots-clés : Inondation urbaine, Modèle hydrodynamique, Simulation 2D, Incertitudes, Régime d'écoulement

\section{INTRODUCTION}

Because stakes are concentrated in urban environment, flood modelling should be carried out there with high accuracy. From an engineering point of view, the more frequent method is the use of the 2-D shallow water equations. If one can show that such a method is generally convenient [El Kadi Abderrezzak, et al., 2009], one can identify several causes for uncertainty, most of them are not linked to the modelling method but to the difficulty in taking into account the physical processes or in obtaining the enough detailed or accurate input data.

Here below, are detailed some of these causes trying to quantify and to distinguish between three categories: estimating the inputs, the complexity of the processes and the features of the environment.

\section{EFFECT OF THE INPUTS}

\section{II.1. Typology of the inputs}

The extent of the floods and their severity first depend of the inputs coming from the upstream of the flooded area and of the evacuation capacity of the corresponding flows. The causes of urban floods are multiple: overflow due to the water elevation of a stream, of the sea or a lake, overflow 
of a sewage network that can transport rainfall waters but can be also the outlet of some basins, of the underground water table, run off with flow concentration in the streets. The water is evacuated by the sewage network, the streams, the street network or through infiltration although this latter one is often reduced in urban environment.

Quantifying the inputs to the flooded area is thus particularly complicated by the possibility of two directions exchanges between the sewage network and the street. Consequently, a detailed modelling should include both the surface flows often concentrated in the streets and the flows in the sewage network. If only the flooded area is modelled, the capacity of input or output of the sewage network should be considered as an uncertainty about the inputs. For high floods, this assumption can be accepted if one compares this kind of uncertainty to the one on the main inputs.

For instance, in case of overflow from a stream, the uncertainty range of the flow discharge is often $15 \%$ or more [Lang, et al., 2006], even 3 to $5 \%$ if a gauging or another measurement during flood is performed close to the flooded area. As often, a large part of an additional input to the stream is sent to the floodplain, the flow capacity of the sewage network should be compared to these 3 to $15 \%$ of the stream flow. Of course, if the stream discharge is not measured but should be representative of a flood frequency, the uncertainty linked to the statistical law fitting of the flow discharges should be added to the measurement uncertainty.

In the case of a flood due to direct runoff following heavy rainfall, one can compare the project rainfall that was used for dimensioning the drainage network to the uncertainty of the rainfall inputs. This latter uncertainty is constituted of two parts: an error about the local measurement of the rainfall and an error of the spatial distribution. In order to illustrate the effect of this latter error, the example of the town of Marseille is selected: the district of the Vieux Port was studied in the framework of the RIVES (Urban Flood Risks and Scenarios Assessment) project funded by ANR, the French Research Agency [Paquier, 2009].

\section{II.2. Example of a district of Marseille}

The studied district is completely urbanised and extends over a whole basin (area of about $3 \mathrm{~km}^{2}$ ) from the crest of the hills culminating at about $120 \mathrm{~m}$ A.S.L. down to the Vieux Port harbour communicating with Mediterranean Sea (Fig. 1).

The slopes can be over $10 \%$, which leads to transit time to the streets very short (a few minutes). All the inflows come from the rainfalls that can either infiltrate or be drained through the sewage network or arrive directly into the streets. A two-dimensional modelling of the flows in the streets was performed using the Rubar 20 software that solves shallow water equations. This software is adapted to the rapid flows [El Kadi Abderrezzak, et al., 2009]. The computational mesh (Fig. 2) includes 72664 cells (triangles at the crossroads and quadrilaterals along the streets). The mesh was created by CETE Méditerranée starting from the map of the built-up blocks as designed in the database of the urban area [Pons, 2009; Pons, 2010].

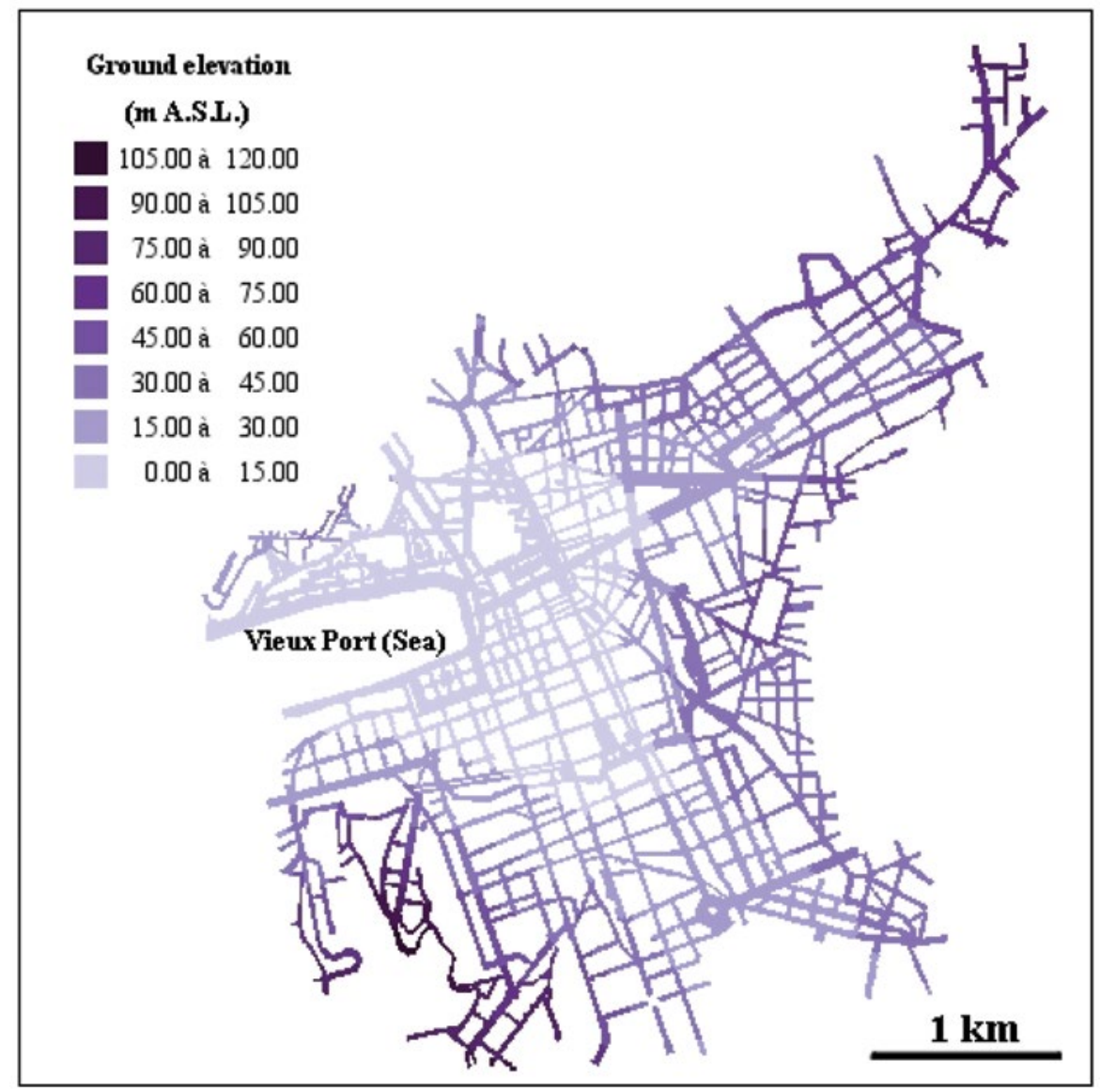

Figure 1: Topography of the district of Vieux Port and street network pattern. 


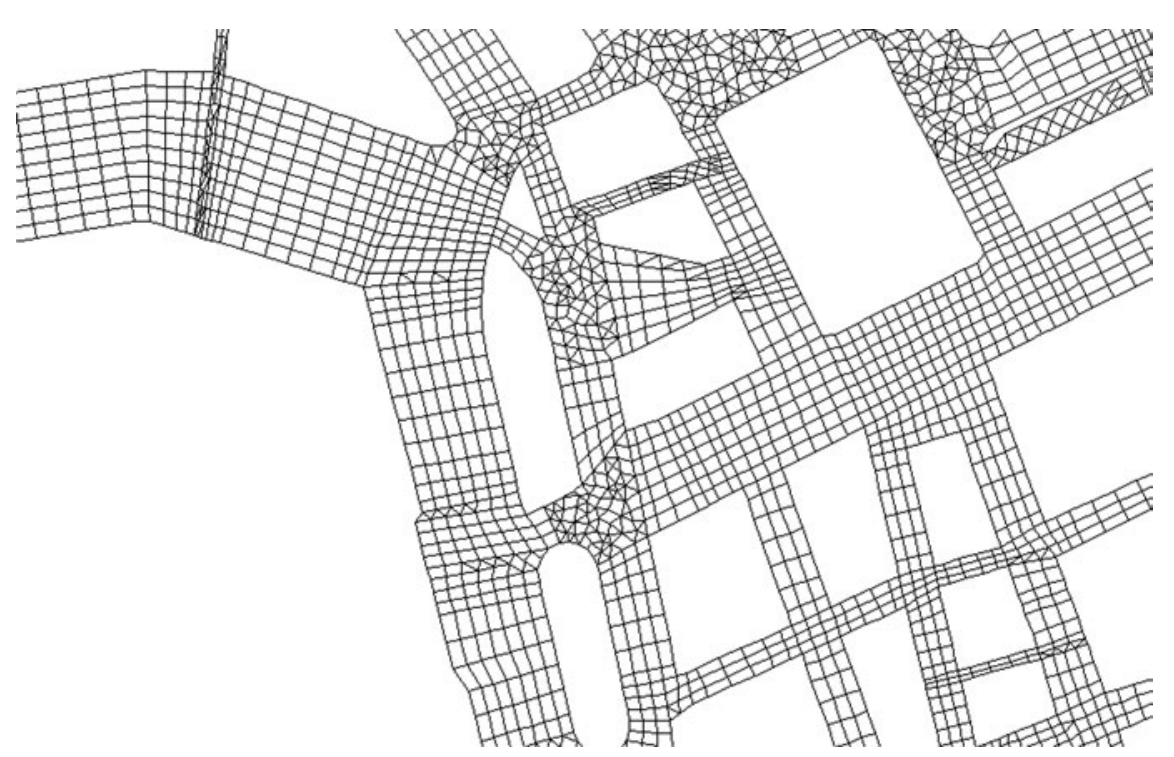

Figure 2: Zoom on the computational mesh close to the Vieux Port harbour.

Over the whole urban area, the Technical Services of the Town Authority own 24 rain gauges with records over an average of twenty years. These data permitted to calibrate a rainfall simulator (Sampo-TBM software developed by Irstea [Leblois and Creutin, 2013]). The use of this simulator for the September 2000 flood (more than $200 \mathrm{~mm}$ during 3 hours) led to defining several potential rainfall distributions (Fig. 3) with different space distribution but all in agreement with the structure of the rainfall field structure. All these rainfalls provide at the location of the rain gauges (among which the one located in the Vieux Port district) the measured rainfall amount but the amounts vary out of these latter locations.

One calculation using the 2-D hydrodynamic model will include one of these rainfall distributions as the inflow. The difference (mean quadratic deviation) between the results of two simulations with two different rainfall distributions reaches a maximum of about $1.3 \mathrm{~cm}$ for an average peak water depth over the studied area of about 10 centimetres (Fig.4). If one compares the results of a hydrodynamic simulation coming from a distributed rainfall issued of the rainfall simulator with the ones coming from an inflow equal to a constant rainfall over the whole area (rainfall measured at the rain gauge located in the Vieux Port and extended to the whole area), one can find an average difference of the same order. This deviation is equivalent to the deviation $(2 \mathrm{~cm})$ provided by a simulation in which one decreases the rainfall by an intensity of $30 \mathrm{~mm} /$ hour (simplified method to represent the evacuation capacity of the sewage network). Particularly, in this latter simulation, the deviation is more important for the peak velocities (30\% less) than for peak water depths because some very strong peak velocities (possibly unrealistic) can be generated by strong rainfall intensities over steep slopes.

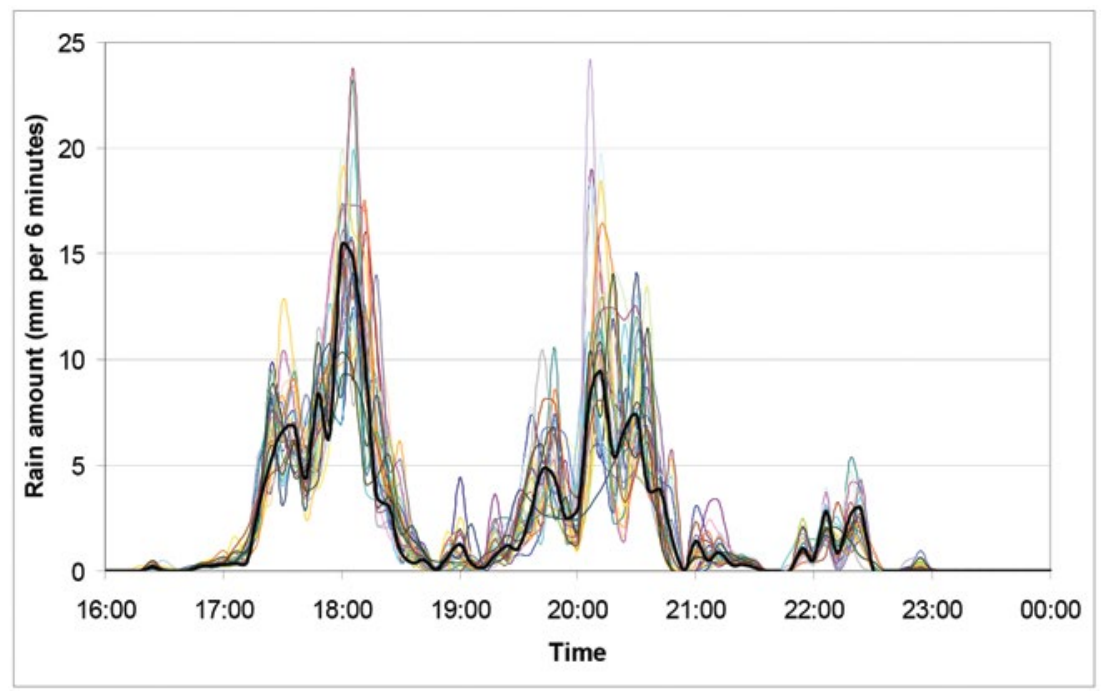

Figure 3: Rainfall averaged over the whole Vieux Port district for the September 2000 event. Local time is in hours and minutes. Results of about 30 various Sambo-TBM simulations are shown. 


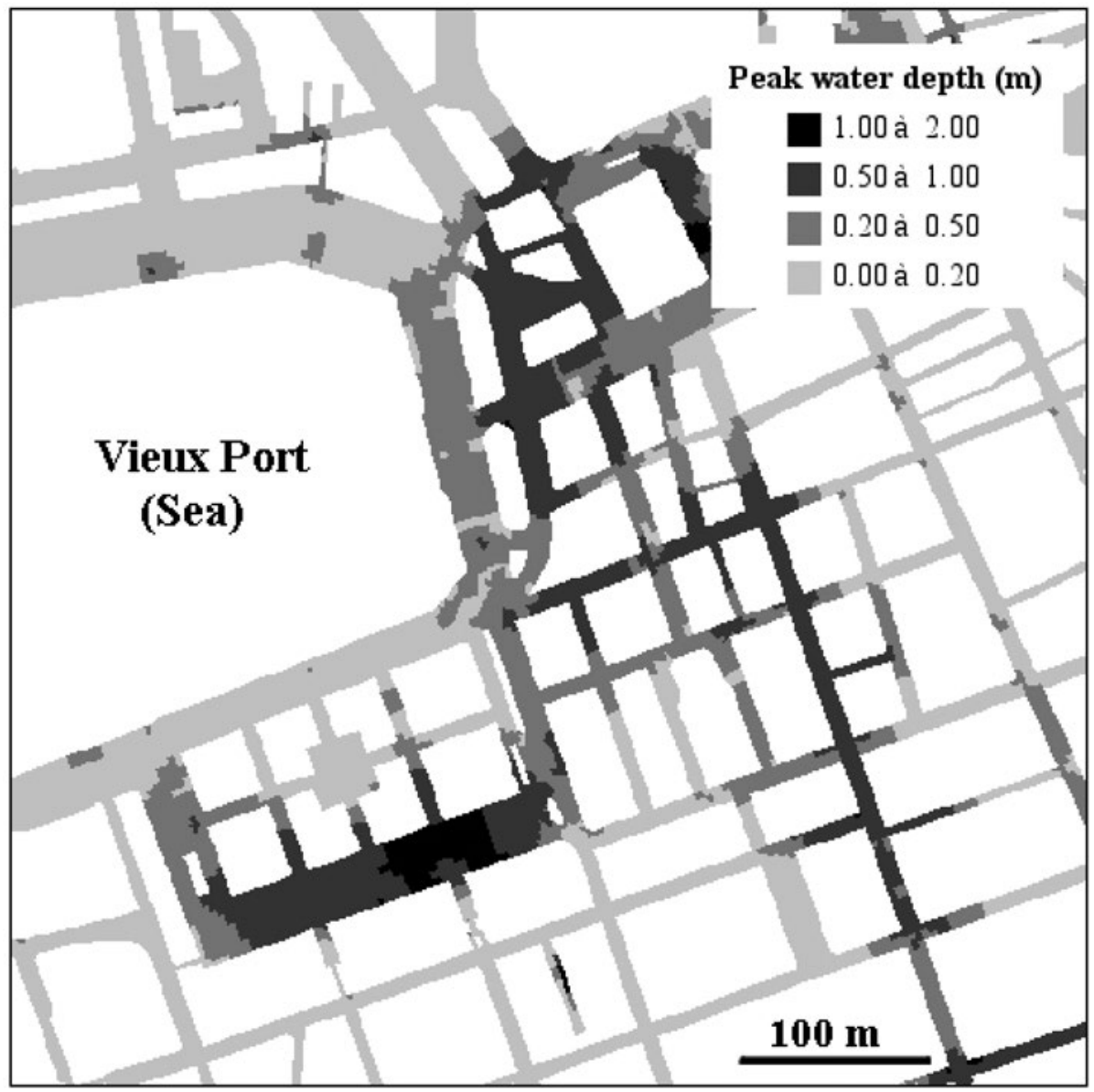

Figure 4: 2-D model of the Vieux Port district (zoom). Peak water depth.

\section{COMPLEXITY OF THE FLOWS}

The flood type influences the type of flow met in urban flooding. For instance, a slow and long river flood is characterized by water elevation in the flood plain becoming identical to the one in the main channel without additional risk in urban area because velocity in the streets remains close to average velocity in the floodplain. However, in a lot of other cases, a rapid flow velocity (over $1 \mathrm{~m} / \mathrm{s}$ ) can occur in the streets that become the priority channels for the flood propagation while slow flows can remain in the sheltered areas thanks to some obstacles often met in the floodplains. Thus, the distribution of the flows inside the urban environment is often a main concern to assess the actual risk level. Particularly, where the slopes are steep, the strong velocities allied to low water depths lead to supercritical flows. Fig. 5 from the 2-D calculation about the example of Marseille shows that subcritical and supercritical flows can alternate; indeed, the widening at a crossroad can create a slow down, which leads to a local change in the flow regime creating a hydraulic jump.

In the case of steep slopes ( 1 to $5 \%$ ), experimental studies at LMFA (Fluid Mechanics and Acoustics Laboratory, INSA Lyon, France) showed that a lot of different patterns can appear for a model of four $(0,3 \mathrm{~m}$ wide and $2 \mathrm{~m}$ long) channels crossroad with 90 degrees angles [Mignot, et al., 2008b]. For these latter flows, a 2-D modelling can provide accurately (error in flow distribution less than 5\%) the typology of the flow patterns and their main features [Mignot, et al., 2008a]. If the flows are less strongly supercritical (only locally supercritical), other experiments at LMFA showed that the local pattern stands more complex which leads to a stronger difficulty for 2-D modelling to provide the flow distribution (error up to $20 \%$ ) because of the stronger influence of the downstream conditions [El Kadi Abderrezzak, et al., 2011]; the local errors of water depths and velocities can also increase and reach $50 \%$ if the hydraulic jumps are wrongly located [Lewicki, et al., 2010].

In the case of the 1988 flood in Nimes, these latter uncertainties lead to difficulties in calibrating a 2-D hydrodynamic model [Mignot, et al., 2006]; but one can also identify other processes that can create strong variations of peak water depth (more than $20 \%$ of peak water depth) very locally (for instance, from one side of a street to the opposite one). These variations can be also found in laboratory experiments [Paquier, 2003]; they are created by flow reflecting against some obstacles or the front walls of the buildings and by wave amplification in case the main flow is strongly curved (example of the deviation into a perpendicular street or of a strong change in the street width).

\section{URBAN ENVIRONMENT FEATURES}

Urban environment is characterized by a natural topography superposed to typically urban features that include a reshaping of topography, the addition of buildings and streets as well as introducing obstacles of varied shape that characterize human use of the environment (bus stops, side walks, etc). 


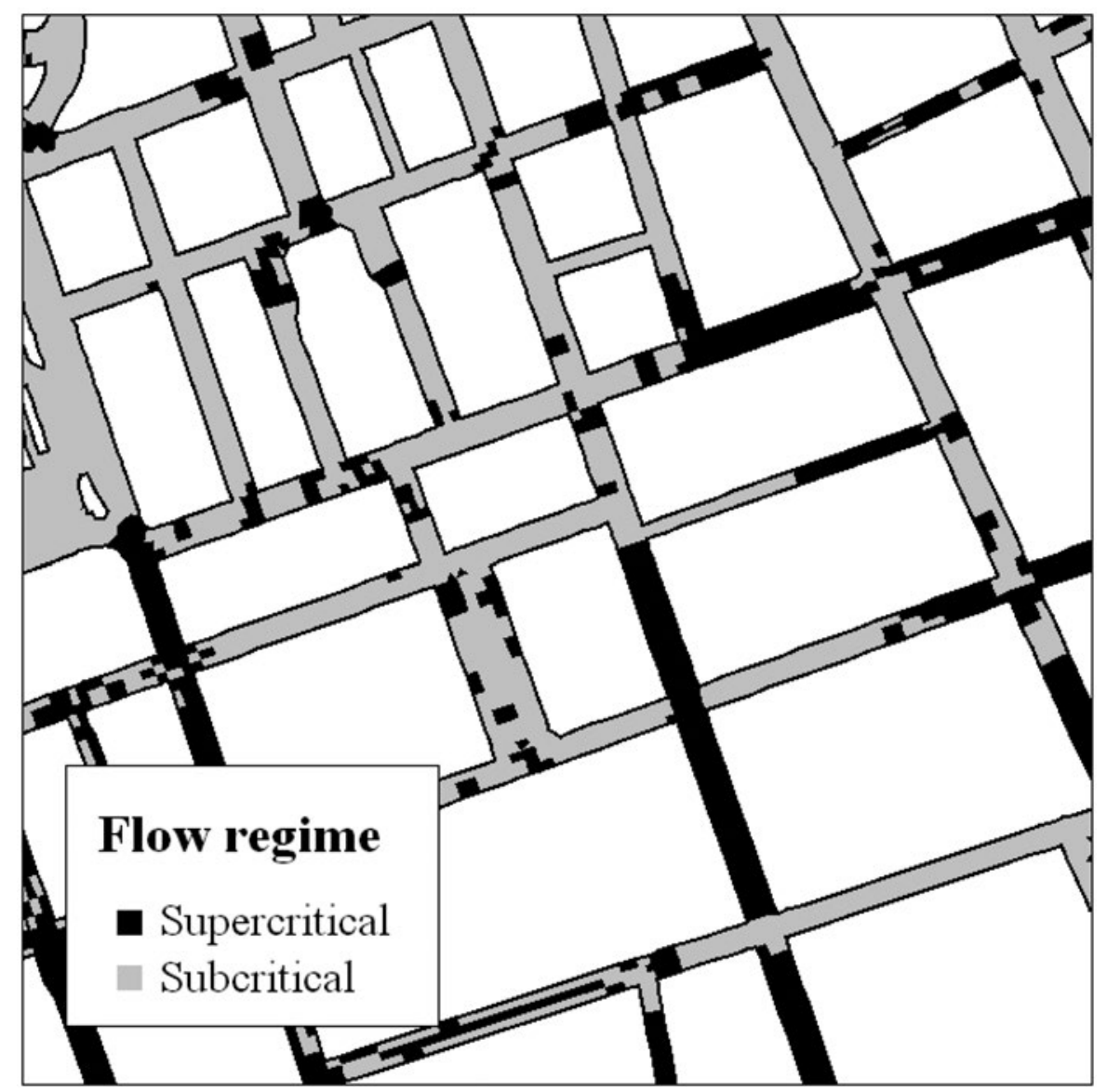

Figure 5: 2-D model of the Vieux Port district (zoom). Flow regime.

Among these obstacles, one should specifically consider cars that stand as fixed obstacles a long as water depths and velocities remain low but that become mobile by floating or sliding as soon as water depths exceed a few tens of centimetres, the process being amplified by the flow velocity. The transport of cars and their stop if the conditions strongly reduce water depth and velocity can cause high changes in flow features. The more striking process is the creation of temporary dams (and the breaking of these dams that follows), which can block the flow through a street strongly reducing the flow capacity and locally increasing water depth and velocity.

Laboratory experiments were carried out at LMFA in the framework of the RIVES project. In a crossroad model made by three flumes $(0.3 \mathrm{~m}$ wide and $2 \mathrm{~m}$ long) forming a T-junction, a few vehicles (scaled cars) were placed in the upstream flume ; then, flow discharge was increased till the vehicles were carried by the flow. The water depth at the immediate upstream of the junction (where the effect of the cars introduction was stronger) could increase by $50 \%$ if no dam is formed and up to $100 \%$ in case of partial or total flow blockage [Paquier, 2009]. Such a blockage by the cars stopping at the junction in which the velocity decreased because the flow was shared between the two downstream flumes has a $10 \%$ occurrence probability. Transferring experimental conclusions to field is not straightforward because a lot of factors, among which the geometrical detailed features and the downstream controls, can influence the processes ; however, as was observed during the Nîmes 1988 flood, the flow blockage by car dam is rather frequent during extreme urban floods and should be taken into account for a real estimate of the potential consequences of the floods and, particularly, for a local assessment of the peak water depth [Paquier, 2009].

One other major factor of the flow processes in urban environment is the water exchanges between the street network and the built-up areas. The increase of the inflow to the inside of the built-up areas has two consequences: on the one hand, the increase of the damages inside the buildings and, on the other hand, the damping of the flows, which reduces the floods in the downstream areas. Modelling these effects is difficult because it requires characterizing both the exchange patterns between streets and built-up areas and the flow propagation inside the built up areas. Due to these latter difficulties, the exchanges can be neglected for dense urban areas, either only the street network is represented (it was the case in the here above example of Marseille); or, one can use a 2-D model of the whole area without describing the flows in a detailed way either using a roughness representing the decrease of flow conveyance inside the buildings or introducing a porosity that permits to describe the storage capacity inside the built up area [Guinot, 2012]. One can also use a detailed description of the buildings structure, of the street components and of the openings ; finally, all these elements that individually have only a local influence can play a part in the global pattern of flooding through the flow distribution; the main limit to this detailed description is then the time (for the description and the calculation) that increases tremendously while the uncertainty range could not be so much reduced because of the remaining uncertainty about other parameters [Chen, et al., 2012]. 
Similar question can be raised if one wishes to describe the street network in a detailed way. For instance, during the RIVES project, the LRPC (Regional Laboratory for Bridges and Roads, Clermont, France) built a physical model of a town district (14 streets) in order to test the effect of local changes in urban environment (modifying the shape of a crossroad, the cross profile of one street, etc); according to the category of change and the flood severity, these effects could be either an increase of flow discharge by $20 \%$ in one street with direct consequences on water depth and velocity in that street or changes below $1 \%$ for all the hydraulic parameters [Paquier, et al., 2009].

Moreover, knowing the flow discharge within a street is not enough to provide the water depths and velocities because of the flow complexity as explained in $\$ 3$ here above but also because of the local obstacles and the detailed cross profiles of the streets [Bazin, et al., 2012] as well as all the parameters used to quantify the various head losses.

The main one among these latter parameters is the bottom friction coefficient (generally Manning coefficient) for which the uncertainty can exceed $50 \%$ if calibration is not carried out [El Kadi Abderezzak, et al., 2009]; one part of this uncertainty is generated when one will include - in the Manning coefficient - « macro roughness » such as sidewalks, gutters, vehicles, etc, which is the common method if such roughness is not explicitly detailed; another part of this uncertainty comes from the estimate of the "usual" roughness of a street that will receive a lot of urban waste but also sediments, plants, etc that modify the surface behaviour during one flood. The calibration of Manning coefficient (and other head loss coefficients if any) is thus necessary for every field case and every model type but, in practice, is limited by the uncertainty linked to the inflows and the flow complexity or, very often, by the lack of observation data.

\section{CONCLUSIONS}

Solving two-dimension shallow water equations permits to model the flows met during urban floods and, particularly, to assess the flow distribution through a street network. The estimates of the inflows or of the friction coefficient generally influence all the results in a homogeneous way. Thus, these parameters should be the first ones to be calibrated.

The local assessment of a water depth is often more difficult because of the flow complexity, particularly, at the crossroads in which the flow distribution depends of a lot of local parameters. These parameters can be linked with the modelling process (type of model, size of elementary cell, etc) but can also come from random events (cars dam blockage for instance) for which only a statistical approach or a scenarios approach are adapted.

The main consequence stands in a resulting uncertainty for local flood hazard parameters over $10 \%$ in the majority of the cases of urban floods.

\section{ACKNOWLEDGEMENTS AND THANKS}

The study presented here above was initiated during the RIVES project funded by ANR. The authors thank all the partners of the RIVES project.

\section{REFERENCES}

Bazin P.H., Bessette A., Mignot E., Paquier A. \& Rivière N. (2012) - Influence of detailed topography when modeling flows in street junction during urban flood. Journal of Disaster Research. 7(5) 560-566

Chen A. S., Evans B., Djordjević S. \& Savić D.A. (2012) - A coarse-grid approach to representing building blockage effects in 2D urban flood modelling. Journal of Hydrology. 426-427 $1-16$

El Kadi Abderrezzak K., Paquier A. \& Mignot E. (2009) Modelling flash flood propagation in urban areas using a two-dimensional numerical model. Natural Hazards. 50 433-460

El Kadi Abderrezzak K., Lewicki L., Paquier A., Riviere N. \& Travin G. (2011) - Division of a critical flow at three branch open channel intersection. Journal of Hydraulic Research. 49(2) 231-238

Guinot V. (2012) - Multiple porosity shallow water models for macroscopic modelling of urban floods. Advances in Water Resources. 37 40-72

Lang M., Perret C., Renouf E., Sauquet E. \& Paquier A. (2006) - Incertitudes sur les débits de crue. La Houille Blanche Revue Internationale de l'Eau. (6) 33-41

Leblois E., CReutin J.D. (2013) — Space time simulation of intermittent rainfall with prescribed advection field: adaptation of the turning band method. Water Resources Research. 49 3375-3387

Lewicki L., Paquier A., El Kadi Abderrazzak K. \& Rivière N. (2010) - Uncertainty in 2-D hydraulic modelling: a case study of an experiment in transcritical flow. Canadian Journal of Civil Engineering. 37 1014-1023

Mignot E., Paquier A. \& Haider S. (2006) - Modeling floods in a dense urban area using 2D shallow water equations. Journal of Hydrology. 327(1-2) 186-199

Mignot E., Paquier A. \& Rivière N. (2008) - Experimental and numerical modeling of symmetrical four-branch supercritical cross junction flow. Journal of Hydraulic Research. 46(6) 723-738

Mignot E., Rivière N., Perkins R. \& Paquier A. (2008) - Flow patterns in a four-branch junction with supercritical flow. Journal of Hydraulic Engineering-ASCE. 134(6) 701-713

PAQUier A. (2003) - Ecoulements de surface lors des fortes inondations en ville. La Houille Blanche-Revue Internationale de l'eau. 6 89-93

PAQUiER A. (2009) - Rapport final du projet RIVES « Risque d'inondation en ville et évaluation de scénarios". Cemagref, Lyon, France

Paquier A., Tachrift H., Riviere N. \& El Kadi Abderrezzak K. (2009) - Assessing the effects of two non-structural flood mitigation measures using laboratory and real cases. Road map towards a flood resilient urban environment, September 2009, Paris, France. Proceedings of Final Conference of the COST action C. 22

Pons F. (2009) - Étude hydraulique du bassin versant du Vieux-Port de Marseille. Traité d'hydraulique environnementale - de la goutte de pluie jusqu'à la mer, Exemples d'application des modèles numériques en ingénierie. Hermès-Lavoisier, Paris. 8 27-44

Pons. F. (2010) - Hydraulic study of the Marseille Vieux-Port river basin. Environmental hydraulics series, Practical Applications in Engineering. ISTE, London. 167-181 